\title{
Femtosecond laser microstructuring and bioactive nanocoating of titanium surfaces in relation to chondrocyte growth
}

\author{
Justus F Ilgner, Slavomir Biedron, Elena Fadeeva*, Boris Cichkov, Doris Klee, Anneke Loos, Eveline Sowa-Soehle, \\ Martin Westhofen
}

From 2nd Scientific Meeting of the Head and Neck Optical Diagnostics Society

San Francisco, CA, USA. 23-24 January 2010

\section{Introduction}

Titanium implants can be regarded as the current gold standard for restoration of sound transmission in the middle ear following destruction of the ossicular chain by chronic inflammation. Many efforts have been made to improve prosthesis design, while less attention had been given to the role of the interface. We present a study on chemical nanocoating on microstructured titanium contact surface with bioactive protein.

\section{Materials and methods}

Titanium samples of $5 \mathrm{~mm}$ diameter and $0,25 \mathrm{~mm}$ thickness were structured by means of a Ti:Sapphire femtosecond laser operating at $970 \mathrm{~nm}$ with parallel lines of $5 \mu \mathrm{m}$ depth, $5 \mu \mathrm{m}$ width and $10 \mu \mathrm{m}$ inter-groove distance. In addition, various nanolayers were applied to PVDF foils, while bone matrix protein 7 (BMP-7) was linked to the outer coating layer.

\section{Results}

Chondrocytes could be cultured on microstructured surfaces without reduced rate of vital / dead cells compared to native surfaces. Chondrocytes also showed contact guidance by growing along ridges particularly on $5 \mu \mathrm{m}$ lines. On PVDF foils, chondrocyte growth was doubled in contact with BMP-7 compared to hydrogel layer or native surface.

\section{Discussion}

According to these results, relative preference for cell growth on titanium prosthesis contact surfaces compared to non-contact surfaces (e.g. prosthesis shaft) can

Laser Zentrum Hannover e.V., Hannover, Germany be achieved by nanocoating. Relative selectivity induced by microstructures for growth of chondrocytes compared to fibrocytes is subject to further evaluation.

Published: 29 October 2010

doi:10.1186/1758-3284-2-S1-030

Cite this article as: Ilgner et al.: Femtosecond laser microstructuring and bioactive nanocoating of titanium surfaces in relation to chondrocyte growth. Head \& Neck Oncology 2010 2(Suppl 1):O30.
Submit your next manuscript to BioMed Central and take full advantage of:

- Convenient online submission

- Thorough peer review

- No space constraints or color figure charges

- Immediate publication on acceptance

- Inclusion in PubMed, CAS, Scopus and Google Scholar

- Research which is freely available for redistribution

Submit your manuscript at www.biomedcentral.com/submit
C Biomed Central 